anales de psicología / annals of psychology

2019, vol. 35, nº 1 (january), 156-165

http://dx.doi.org/10.6018/analesps.35.1.338381
(C) Copyright 2019: Editum. Servicio de Publicaciones de la Universidad de Murcia. Murcia (Spain) ISSN print edition: 0212-9728. ISSN on line edition (http://revistas.um.es/analesps): 1695-2294.

On line edition License Creative Commons 4.0: BY-NC-ND

\title{
A meta-analytical review of the responses in the MMPI-2/MMPI-2-RF clinical and restructured scales of parents in child custody dispute
}

\author{
Laura Redondo ${ }^{1}$, Francisca Fariña ${ }^{1}$, Dolores Seijo ${ }^{2}$, Mercedes $\mathrm{Novo}^{2}$, and Ramón Arce, ${ }^{2}$,
}

1 Departamento AIPSE, Universidad de Vigo (Spain)

2 Psicología Organizacional, Jurídica Forense y Metodología de las Ciencias del Comportamiento, Universidad de Santiago de Compostela (Spain)

\begin{abstract}
Título: Una revisión meta-analítica de las respuestas en escalas clínicas y reestructuradas del MMPI-2/MMPI-2-RF de padres en disputa por la custodia.

Resumen: La evaluación de las capacidades parentales para el ejercicio de la guarda y custodia de los hijos incluye el ajuste psicológico y la psicopatología. En esta evaluación, además, se ha de sospechar disimulación. El instrumento psicométrico de referencia para dicha evaluación es el MMPI. Para conocer de lo informado por los progenitores en disputa por la custodia nos planteamos una revisión meta-analítica de las escalas clínicas y las escalas clínicas reestructuradas. Encontramos 21 estudios primarios con progenitores (se descartaron los diseños de simulación de progenitores en disputa) de los que obtuvieron 291 tamaños del efecto para las escalas clínicas y 1 para las reestructuradas. Los resultados mostraron un tamaño del efecto promedio positivo, significativo, y generalizable en las escalas $\mathrm{Hy}, \mathrm{Pd}$ y $P a$; negativo, significativo y generalizable en las escalas $M a$ y $S i$ y no generalizable en las escalas $P t$ y $S_{c}$, y un tamaño del efecto promedio insignificante en las escalas $H s$ y $D$. Se estudió el género como moderador, no hallándose diferencias entre padres y madres. Se discuten las implicaciones de los resultados para la práctica forense.

Palabras clave: Disputa por la custodia; MMPI-2; Escalas clínicas; Escalas restructuradas; Separación; Capacidad parental.
\end{abstract}

\section{Introduction}

The primary objective of the guidelines governing the procedures of forensic psychologist in cases involving parental child custody litigation is to evaluate the wellbeing and needs of the child, the parenting skills required to satisfying these needs, and the adjustment between both. Parenting skills are evaluated to identify childrearing skills, and assess the repercussions of poor parenting abilities. Among the latter we find the clinical conditions (psychopathology and psychological adjustment) on account of their potential effect on a parent's capacity to attend to the wellbeing and needs of their children (American Psychiatric Association [APA], 2010; Martindale, Martin, Austin, \& the Task Force Members, 2007; Arce, Arch, Fariña, Muñoz, \& Seijo, 2016), leading in severe cases to parents losing child custody (Arce, Fariña, \& Seijo, 2005). Moreover, in forensic contexts intentionally biased responses should always be suspected, which in this context entails a differential diagnosis of feigning. This requires a multi-method approach (Graham, 2011), consisting of a clinical interview and psychometric measurements. The standard clinical interview (First, Williams, Karg, \& Spitzer, 2015) is

* Correspondence address [Dirección para correspondencia]: Ramón Arce. Unidade de Psicoloxía Forense. Facultade de Psicoloxía. Campus Vida, s/n. 15782 Santiago de Compostela, A Coruña (Spain). E-mail: ramon.arce@usc.es

(Article received: 26-7-2018; revised: 21-8-2018; accepted: 1-11-2018)
Abstract: Parental attribute evaluation in relation to child custody comprises psychological and psychopathology. Additionally, defensiveness must be suspected on this setting. The worldwide reference psychometric measurement instrument for this purpose is the MMPI. With the aim of knowing the responses of parents litigating by child custody, a metaanalytic review of the responses to clinical and restructured scales was performed. A total of 21 primary studies (studies with a simulation design i.e., participants were instructed to answer as parents litigating by child custody were found were disregarded) were found, obtaining 291 effect sizes for clinical scales and 1 for restructured scales. The results showed positive, significant and generalizable mean true effect size in the $H y, P d$ and $P_{c}$ scales; a negative, significant and generalizable in the $M a$ and $S i$ scales, and non-generalizable in the Pt y $S_{c}$ scales; and a trivial mean true effect size in the $H s$ and $D$ scales. Parent gender was studied as a moderator having no found differences between the responses of mothers and fathers. The implications of the results for forensic evaluation practices are discussed. Keywords: Child custody dispute; MMPI-2; Clinical scales; Restructured scales; Separation; Parental attributes.

invalid for evaluating feigning (Alonso, Moscoso, \& Salgado, 2017), which has prompted the design of a forensic-clinical interview that includes a tool for evaluating feigning (Vilariño, Arce, \& Fariña, 2013). Nevertheless, it fails to correctly classify feigning, which underscores the need for complementary measures. Thus, psychometric instruments should not be restricted to evaluating psychopathology and psychological adjustment, but also feigning in all its forms (Strong, Greene, Hoppe, Johnston, \& Olesen, 1999). The instrument fulfilling these requirements for forensic evaluation by measuring both feigning and psychological adjustment, as well as being the most extensively used by forensic psychologists for this purpose ( $>90 \%$ of cases of custody litigation), was the MMPI (Ackerman \& Pritzl, 2011; Quinnel \& Bow, 2001), and currently the MMPI-2 (Arce, Fariña, Seijo, \& Novo, 2015), and the MMPI-2-RF (Sánchez, Ampudia, Jiménez, \& Amado, 2017). As for the evaluation of psychopathology and psychological adjustment, the MMPI-2 (Butcher, Dahlstrom, Graham, Tellegen, \& Kaemmer, 1989) consists of 9 clinical scales (initially 10 , but Masculinity-Femininity has been deleted): Hypochondriasis (1-Hs), Depression (2-D), Hysteria (3-Hy), Psychopathic Deviate (4-Pd), Paranoia (6-Pa), Psychasthenia (7-Pt), Schizophrenia (8-Sc), Hypomania (9-Ma), and Social introversion (0-Si). The $H s$ scale (32 items) evaluates excessive concerns about illness, unfounded somatic complaints, or minor ailments, and persistent complaints of medically unexplainable physical symptoms. The $D$ scale (57 items) measures depressive symptomology characterized by 
feeling low, no hope for the future, and overall dissatisfaction with oneself. The Hy scale (60 items) measures specific physical complaints, and an evaluation of positive attitudes of themselves and others. The $P d$ scale (50 items) evaluates problematic family relationships, trouble with the law, social introversion, social alienation, and social avoidance. The $\mathrm{Pa}$ Scale (40 items) assesses persecutory beliefs ( $\mathrm{Pa} 1$ ); intense emotional sensitivity to criticism ( $\mathrm{Pa} 2$ ); and trusting, virtuous outlook about people and denial of cynicism and mistrust (Pa3). The Pt Scale (48 items) evaluates the inability to control actions or thoughts in spite of their unadapted nature, abnormal fear, self-critical, lack of concentration, and feelings of guilt. The Sc Scale (78 items) measures social alienation, that is, feeling mistreated, misunderstood, and unloved (Sc1); emotional alienation, that is, feelings of fear, depression, and apathy $\left(S_{c 2}\right)$; lack of control of the ego, cognitive, that is, processesing strange thoughts, unreal feelings, difficulties in concentration and memory $\left(S_{c} 3\right)$; lack of control of the conative ego, leading to the idea that life is strange, excessively worried, and in stressful situations seeks refuge in fantasies and dream world ( $\left.S_{C} 4\right)$; lack of control of the ego, defective inhibition, that is, lack of control over one's own emotions and impulses $\left(S C_{5}\right)$; and strange sensorial experiences such as sensitive feet, and other unusual sensorial experiences, hallucinations, bizarre thoughts and ideas of reference $(S c \sigma)$. The $M a$ Scale (46 items) evaluates hypomanic (e.g., mood swings, excitement, flight of ideas) and depressive symptoms, family relations, moral values, worries about physical health and body. The Si Scale (69 items) measures the tendency for social avoidance, assertiveness, and social skills. Tellegen et al. (2003) developed the restructured clinical scales with two objectives in mind. First, the minimization of the relationship among the clinical scales, with the general subjective distress and the negative affect common to all of them. For this purpose, the Demoralization Scale (Rcd) was designed to encompass items measuring subjective distress and negative affect. Second, once these items on the clinical scales were removed, the restructured clinical scales were designed to identify the core components, substantive and distinctive of each one, resulting in the Somatic Complaints (Rc1; 74.1\% items overlapping with 1-Hs), Low Positive Emotions (Rc2; 47.1\% with 2-D), Cynicism (Rc3; 33.3\% with 3-Hy), Antisocial Behaviour (Rc4; 40.9\% with 4-Pd), Ideas of Prosecution (Rc6; 76.5\% with 6-Pa), Dysfunctional Negative Emotions (Rc7; 33.3\% with 7-Pt), Abnormal Behaviour (Rc8; 55.6\% with 8-Sc), and Hypomanic Activation (Rc9; 28.6\% with 9-Ma) scales. In the restructured form, the MMPI-2-RF, the clinical scales were replaced by the restructured clinical scales that are also computed on the MMPI-2 as all of the items on the MMPI-2-RF have been included. Thus, the restructured clinical scales (Tellegen et al., 2003) with their clinical counterparts (the Rcd scale has no counterpart to the clinical scales), with the exception of the $H y$ scale where the somatic symptoms were removed from the restructured clinical (Rc3), and included in the Rcd scale, and only those referring to cynicism were maintained. Moreover, the RC6 and RC8 scales have also undergone significant changes in the content under evaluation. Thus, the RC6 scale focuses on persecutory beliefs (Pa1), omitting $\mathrm{Pa} 2$ and $\mathrm{Pa} 3$ items that have a sign contrary to persecutory beliefs, which are expected to be assumed in cases of child custody litigation. Likewise, the RC8 scale is centred on abnormal experiences, omitting items on poor family relations, control of impulses, self-esteem, and identity (i.e., the eliminated items were relevant for evaluating parents in child custody litigation). Thus, the clinical and the restructured scales are not entirely interchangeable (Simms, Casillas, Clark, Watson, \& Doebbeling, 2005).

Both separation and divorce entail injury in the psychological adjustment of both parents and their offspring, in particular in terms of high levels of anxiety and depressive symptoms, and in the diagnosis of anxiety and depression (Afifi, Cox, \& Enns, 2006; Amato, 2010; APA, 2013; Blanco, Otero, López, Torres, \& Vázquez, 2017; Bourassa, Allen, Mehl, \& Sbarra, 2017; Seijo, Fariña, Corras, Novo, \& Arce, 2016; Zella, 2017). However, evaluations in forensic setting have found that, in general, subjects under evaluation reported normality. This discrepancy between expected injury and reported injury informs of a systematic measurement error (defensiveness). Succinctly, an estimated one third of parents in child custody litigation bias their responses (Arce et al., 2015; Baer \& Miller, 2002; Strong et al., 1999). Feigning can manifest itself in either of two ways: concealment/denial of clinical symptoms negatively associated to the awarding of custody; and adhering to positive characteristics for exercising child custody. Thus, response bias in the evaluations by parents in child custody litigation may derive from opposite sides of the spectrum: the assumption of characteristics considered to be positive to custody, and denial/concealment of negative ones.

Thus, a meta-analytical review of forensic evaluations (field studies) was undertaken to assess the self-reported psychological adjustment of parents in child custody litigation on the clinical scales (MMPI, MMPI-2), and the restructured (MMPI-2 and MMPI-2-RF), and to compare the data obtained with the normative population, The results of the meta-analysis have served to map the response bias of parents concerning their reported psychological adjustment in forensic evaluations.

\section{Method}

\section{Study search}

Studies for the meta-analysis were obtained by applying two procedures: 1) search for studies in the leading scientific databases (i.e., Scopus, Web of Science, PsycInfo), in the doctoral dissertation database Proquest Dissertations \& Theses; and in the meta search-engine Google Scholar; and 2) a review of the list of references of other meta-analyses and reviews of forensic evaluation with the MMPI (Hathaway \& Mackinley, 1940), MMPI-2 (Butcher et al., 1989) and MMPI- 
2-RF (Ben-Porath \& Tellegen, 2008/2011). The initial search descriptors in the databases were the following meta-tags clinical scales, restructured clinical scales, child custody dispute, MMPI, MMPI-2, MMPI-2-RF, to which keywords were added from the articles selected for study. The entire information contained in each register was taken as an initial search unit. The Study search flowchart is shown in Figure 1. The selected studies were applied the following inclusion criteria:

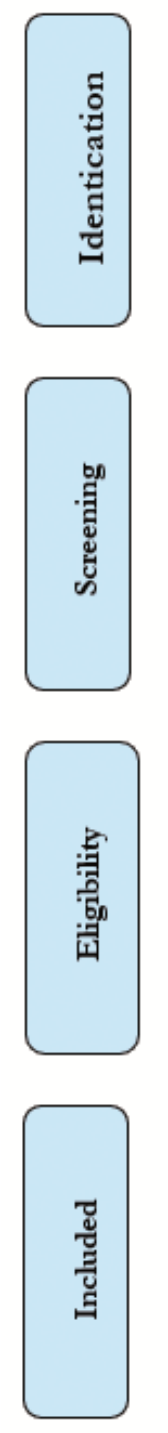

a) The study evaluated parents undergoing a process of separation and child custody litigation.

b) The study evaluated the psychological adjustment of parents on the clinical or restructured scales of the MMPI in any of its versions.

c) The study provided sufficient data for calculating the effect size (i.e., $\mathrm{T}$ scores on the measurement scales, or mean direct scores of the experimental group).

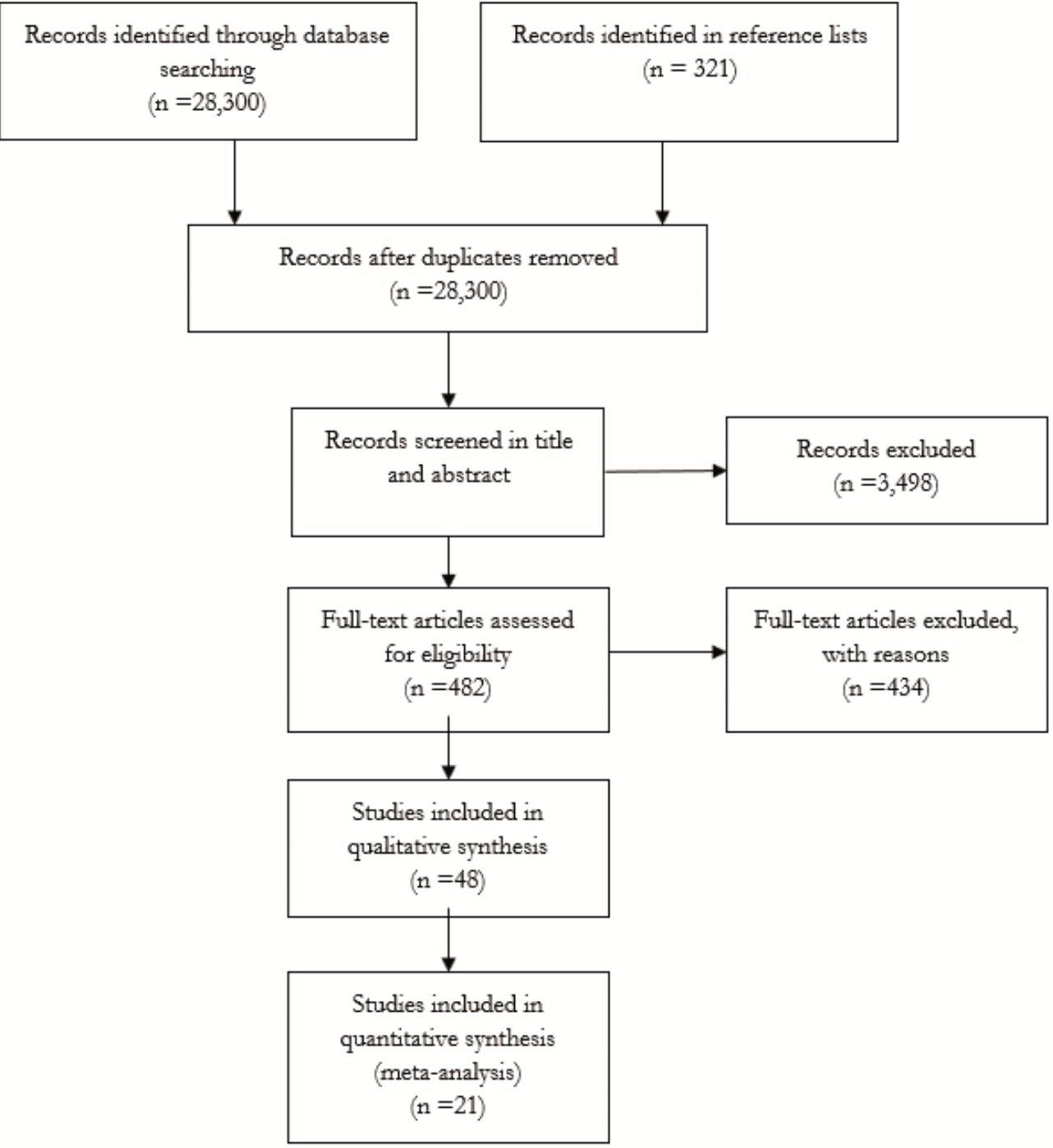

Figure 1. Flow diagram of the meta-analysis.

Of these studies, those based on feigning designs were excluded (exclusion criterion), that is, when participants were instructed to act as if they were parents undergoing a process of separation and child custody litigation. Undoubtedly, subjects in studies with feigning designs are not as equally motivated as subjects in studies under real conditions, that is, subjects in studies with feigning designs are not as implicated in the task (simulated cases of child custody litigation), which undermines their validity (Konecni \& Ebbesen, 1992), and would explain the discrepancies with the results of field studies (Fariña, Arce, \& Real, 1994). Moreover, in feigning designs all of the participants respond under conditions of feigning instructions, whereas in field studies feigning is estimated to affect around a third of parents in child custody 
litigation (Arce et al., 2015; Baer \& Miller, 2002; Fariña, Arce, \& Sotelo, 2010; Strong et al., 1999). Hence, as evaluations in field studies are different to feigning both cannot be compared.

A total of 21 primary studies were included in the metaanalysis, 13 journal articles, 7 doctoral theses, and 1 unpublished study, the effect sizes in one or more basic clinical or restructured scales on the MMPI were calculated. Overall, 291 effect sizes were gathered, 34 for the Depression and Schizophrenia scales; 33 for the $H y, P d$, and $P a$ scales; and 31 for the $\mathrm{Hs}, \mathrm{Pt}, \mathrm{Ma}$ and $\mathrm{Si}$ scales. As for the restructured scales (i.e., RCd, RC1, RC2, RC3, RC4, RC6, RC7, RC8 and RC9), only one study was available in the literature (Archer, Hagan, Mason, Handel, \& Archer, 2012) that fulfilled the meta-analysis inclusion criteria (i.e., population of parents in child custody litigation). A Table with the data and characteristics of these studies, which is too extensive to be attached to this article, can be obtained on request from the corresponding author.

\section{Coding of primary studies}

Two trained and experienced researchers coded separately (inter-coder consistency) the studies according to the following categories: 1) Reference of the study; 2) Type of work (article, doctoral thesis, book/chapter, unpublished study); 3) sample characteristics (i.e., size, gender); 4) name of clinical scales evaluated; and 5) the effect size registered or data required for its computation. After a one-week interval, each coder repeated $50 \%$ of the coding of the studies (intra-coder consistency). The inter- and intra-coder consistency obtained (true concordance, $\overline{\mathrm{K}}$; Fariña, Arce, \& Novo, 2002), that is, corrected by verifying the exact correspondence in the coding, was total $(\widetilde{\kappa}=1)$. So, these coders were consistent with other studies i.e., in other contexts (Fariña, Redondo, Seijo, Novo, \& Arce, 2017). Thus, inter- e intra-coder and intercontexts consistency confirmed the coding was reliable (Wicker, 1975).

\section{Data analysis}

The execution and presentation of the meta-analysis was undertaken in line with the recommendations of RubioAparicio, Sánchez-Meca, Marín-Martínez and López-López (2018). The effect sizes were calculated using Cohen's $d$. The studies showed evaluated data in direct scores as $\mathrm{T}$ scores, comparisons to other evaluation groups, a control group, or no comparison to other groups. The direct scores were transformed into $\mathrm{T}$ scores using the mean scores and deviations of the normative population in the MMPI manuals, and for the remaining studies the mean scores were computed as $\mathrm{T}$ scores. Thereafter, the effect sizes of each clinical scale of each study was calculated by $d$ using Glass' formula (Glass, 1976; Glass, McGaw, \& Smith, 1981) a, with the mean being 50 and the standard deviation 10 . The next step was to perform a meta-analysis of random effects correcting the effect size by the sample error, and the unreliability criterion, the procedure of Schmidt and Hunter (2015). Thus, in line the recommendations of Schmidt and Hunter (2015) the following statistics were calculated: the effect size weighted for the sampling error $\left(d_{\mathrm{w}}\right)$; the standard deviation of $d\left(S D_{\mathrm{d}}\right)$; the standard deviation of $d$ predicted by artifactual errors $\left(S D_{\text {pre }}\right)$; the standard deviation of $d$, after removal of variance due to artifactual errors $\left(S D_{\text {res }}\right)$; the mean true effect size, corrected for criterion unreliability $(\delta)$; the standard deviation of $\delta$ $\left(S D_{\delta}\right)$; the variance accounted by artifactual errors (\%Var); the $95 \%$ confidence interval for $d\left(95 \% \mathrm{CI}_{d}\right)$; and the $80 \%$ credibility interval for $\delta\left(80 \% \mathrm{CI}_{\delta}\right)$. If the confidence interval has no zero, it informed the effect size was significant. If the credibility interval has no zero, it confirmed it encompassed $80 \%$ of potential studies on the same population, meaning $90 \%$ of all the studies would be above the lower limit. If artifactual variance explained the bulk of the variance, $>75 \%$ (75\% rule; Hunter, Schmidt, \& Jackson, 1982), then nonexplained variance was not systematic (homogeneous data). Conversely, if it explained less than $75 \%$, moderators mediated the results (heterogeneous data). Formulas were taken from Schmidt and Hunter (2015). As only one restructured clinical scales was available for correcting the effect size through attenuation, the effect size was interpreted according to Cohen's (1988) categories: 0.20 (small), 0.50 (medium/moderate), and 0.80 (large). Though the study of mean differences is valuable for deriving the implications for forensic practice, it should be complemented with the study of cases according to the recommendations of Amado, Arce, and Herraiz (2015) using the U or Cles statistics, and Cohen's qc statistic (1988) for the comparison of the effect size between two moderators.

\section{Criterion reliability}

The reliability of the Clinical scales was taken from the review of studies of Hunsley, Hanson and Parkeret (1988): $H s(\alpha=.79), D(\alpha=.81), H y(\alpha=.78), P d(\alpha=.71), P a(\alpha=$ .73), Pt $(\alpha=.84), S_{c}(\alpha=.82), M a(\alpha=.71)$, and $S_{i}(\alpha=.81)$; and from the restructured clinical scales of the MMPI-2-RF manual.

\section{Results}

\section{Study of outliers}

Owing to the context of this study where participants were exposed to a psychosocial stressor (couple breakdown) generating clinical symptomatology (Amato, 2010; APA, 2013), neither high scores should be interpreted as outliers as these may be the result of this contingency (cause-effect relation), nor low scores as they were a feigning context where approximately $1 / 3$ of parents in custody litigation feign their responses. Nevertheless, outliers and extreme distributions in field studies with parents in child custody litigation should be 
controlled. No study with extreme values or outliers was found.

\section{Psychological adjustment}

The results (see Table 1) for the $H y, P d$, and $P a$ scales revealed a significant (when 95\% confidence interval for $d$ has no zero, indicating the effect size was significant), positive (litigating parents report more symptoms than in the normative population), with a small to moderate $(0.20>d<0.50)$ and generalizable (the credibility interval has no zero) mean true effect size $(\delta)$. In contrast, for the $P t, S_{c}, M a$, and $S i$ scales, a mean true effect size $(\delta)$ was found to be significantly negative (parents in child custody litigation informed of fewer clinical symptoms on these scales than in the normative population); and a small effect size in the $M a$ scale ( $d=$
$0.20)$, between small to moderate in the $P t$ and $S c$ scales, and moderate $(d=0.50)$ in the $S i$ scale. Moreover, the results for the $M a$ and $S i$ scales were generalizable to other studies and samples of the same population, but this was not so for the $P t$ and $S_{c}$ scales. Finally, a significant and negative mean true effect size was found in the $H s$ and $D$ scales. However, the effect size was fewer than small $(d<0.20)$, as the 50 percentile (mean) of parents in litigation corresponded $\left(\mathrm{U}_{3}=.53\right.$ and .52 for $H s$ and $D$, respectively) with percentiles 53 and 52 of the normative population. Likewise, this effect was not generalizable to additional studies of the population. In short, the lack of an effect on significance prevailed, which rested on a very large $N$ (conducive to a type I error). Thus, parents did not diverge from the normative population in responses on the $H s$ and $D$ scales.

Table 1. Results of the meta-analyses for parents in child custody disputes in clinical scales.

\begin{tabular}{lccccccccccc}
\hline Scale & $k$ & $N$ & $d_{\mathrm{w}}$ & $S D_{d}$ & $S D_{\text {pre }}$ & $S D_{\text {res }}$ & $\delta$ & $S D_{\delta}$ & $\% \mathrm{Var}$ & $95 \% \mathrm{CI}_{d}$ & $80 \% \mathrm{CI}_{\delta}$ \\
\hline $\mathrm{Hs}$ & 31 & 8372 & -0.06 & 0.28 & 0.12 & 0.25 & -0.07 & 0.28 & 18.85 & $-0.10,-0.02$ & $-0.43,0.30$ \\
$\mathrm{D}$ & 34 & 8497 & -0.06 & 0.16 & 0.13 & 0.10 & -0.06 & 0.10 & 66.14 & $-0.10,-0.02$ & $-0.19,0.06$ \\
$\mathrm{Hy}$ & 33 & 8497 & 0.41 & 0.20 & 0.13 & 0.16 & 0.46 & 0.18 & 38.82 & $0.37,0.45$ & $0.23,0.69$ \\
$\mathrm{Pd}$ & 33 & 8497 & 0.30 & 0.20 & 0.13 & 0.15 & 0.36 & 0.18 & 39.72 & $0.26,0.34$ & $0.12,0.59$ \\
$\mathrm{~Pa}$ & 33 & 8497 & 0.41 & 0.12 & 0.13 & 0.01 & 0.48 & 0.01 & 100 & $0.37,0.45$ & 0.48 \\
$\mathrm{Pt}$ & 31 & 8372 & -0.28 & 0.31 & 0.12 & 0.28 & -0.31 & 0.30 & 16.15 & $-0.32,-0.24$ & $-0.70,0.08$ \\
$\mathrm{Sc}$ & 34 & 8497 & -0.30 & 0.31 & 0.13 & 0.28 & -0.33 & 0.31 & 17.25 & $-0.24,-0.26$ & $-0.72,0.07$ \\
$\mathrm{Ma}$ & 31 & 8372 & -0.14 & 0.13 & 0.12 & 0.05 & -0.17 & 0.06 & 86.82 & $-0.18,-0.10$ & $-0.24,-0.09$ \\
$\mathrm{Si}$ & 31 & 8372 & -0.48 & 0.21 & 0.12 & 0.17 & -0.53 & 0.19 & 35.23 & $-0.52,-0.44$ & $-0.77,-0.29$ \\
\hline
\end{tabular}

Note. $k$ : number of studies; $N$ : total sample size; $d_{\mathrm{w}}$ : effect size weighted for sample size; $S D_{d}$ : observed standard deviation of $d ; S D_{\text {pre: }}$ standard deviation of observed correlations predicted from all artifacts; $S D_{\text {res: }}$ standard deviation of $d$, after removal of variance due to artifactual errors; $\delta$ : effect size corrected for criterion unreliability; SD 8 : standard deviation of $\delta$; \%Var: variance accounted by artifactual errors; $95 \% \mathrm{CI}_{d:}$ 95\% confidence interval for $d$; $80 \% \mathrm{CI}_{\delta}$ : $80 \%$ credibility interval for $\delta$.

The percentage of variance explained by the artifactual errors, $<75 \%$, informed of the presence of moderators in the effect of the $H_{s}, D, H y, P d, P t, S_{c}$, and $S_{i}$ scales. Moreover, moderators on the $\mathrm{Pa}$ scale were analysed given that the variance explained by artifactual errors was $100 \%$, which was due to a second order sampling error i.e., the primary studies were not randomly distributed. The systematic moderator analysed and reported in primary studies was gender.

The results in the restructured clinical scales, insufficient for a meta-analytical study $(k=1)$, were corrected for attenuation resulting in a positive and small effect size in the RC6 Scale $(\delta=0.28$ and $\delta=0.37$, for mothers and fathers, respectively); negative and small in fathers in the RC4 Scale $(\delta$ $=-0.18)$; negative and moderate in the Rc1 $(\delta=-0.73)$, Rc2 $(\delta=-0.48), \operatorname{Rc} 3(\delta=-0.65), \operatorname{Rc} 8(\delta=-0.49)$, and Rc9 $(\delta=-$ $0.54)$ scales; and negative and large in the $\operatorname{Rcd}(\delta=-0.84)$, and Rc7 $(\delta=-1.04)$ scales. As for mothers, results exhibited a null effect size in the Rc1 Scale $(\delta=-0.03)$; negative and moderate in the $\operatorname{Rcd}(\delta=-0.47), \operatorname{Rc} 2(\delta=-0.53), \operatorname{Rc} 3(\delta=-$
0.73), Rc4 ( $\delta=-0.64), \operatorname{Rc} 7(\delta=-0-76)$, and Rc8 $(\delta=-0.46)$ scales; and large in the Rc9 $(\delta=-0.95)$ scale.

\section{Gender as a moderator}

The results of the meta-analytical study of gender as a moderator (see Table 2) showed the population of fathers reported normality in Hypochondriasis and Depression; lower levels than normality in Psychasthenia, Schizophrenia and Social Introversion; but higher levels of Hysteria, Psychopathic Deviate, and Paranoia than normality. In comparison, mothers reported normality in Hypochondriasis; higher levels than normality in Hysteria, Psychopathic Deviate and Paranoia; and lower levels of Depression, Psychasthenia, Schizophrenia, and Social Introversion. Comparatively, there were no differences (the confidence intervals of $d$ overlapped in all of the dimensions, and the $\mathrm{q}_{\mathrm{c}}$ comparison was not significant) between fathers and mothers in the self-reported clinical dimensions, that is, psychological adjustment. 
Table 2. Results of the meta-analyses in clinical scales for the gender of the litigator as moderator.

\begin{tabular}{|c|c|c|c|c|c|c|c|c|c|c|c|}
\hline $\begin{array}{l}\text { Scale/ } \\
\text { Subsample }\end{array}$ & $k$ & $N$ & $d_{\mathrm{w}}$ & $S D_{d}$ & $S D_{\text {pre }}$ & $S D_{\text {res }}$ & $\delta$ & $S D_{\delta}$ & $\% \operatorname{Var}$ & $95 \% \mathrm{CI}_{d}$ & $80 \% \mathrm{CI}_{\delta}$ \\
\hline \multicolumn{12}{|l|}{ Hs } \\
\hline Fathers & 11 & 2363 & 0.03 & 0.21 & 0.14 & 0.16 & -0.04 & 0.18 & 40.86 & $-.011,0.05$ & $-0.27,0.20$ \\
\hline Mothers & 11 & 2416 & 0.02 & 0.21 & 0.13 & 0.16 & -0.03 & 0.18 & 41.70 & $-0.10,0.06$ & $-0.26,0.20$ \\
\hline \multicolumn{12}{|l|}{$\mathrm{D}$} \\
\hline Fathers & 12 & 2423 & -0.02 & 0.15 & 0.14 & 0.06 & -0.02 & 0.07 & 83.17 & $-0.10,0.06$ & $-0.11,0.07$ \\
\hline Mothers & 12 & 2472 & -0.1 & 0.22 & 0.14 & 0.52 & -0.11 & 0.18 & 41.59 & $-0.18,-0.02$ & $-0.35,0.12$ \\
\hline \multicolumn{12}{|l|}{ Hy } \\
\hline Fathers & 12 & 2705 & 0.38 & 0.14 & 0.13 & 0.04 & 0.43 & 0.05 & 91.81 & $0.30,0.46$ & $0.37,0.49$ \\
\hline Mothers & 10 & 2074 & 0.22 & 0.22 & 0.14 & 0.18 & 0.25 & 0.20 & 38.78 & $0.13,0.31$ & $-0.00,0.51$ \\
\hline \multicolumn{12}{|l|}{$\mathrm{Pd}$} \\
\hline Fathers & 11 & 2363 & 0.27 & 0.15 & 0.14 & 0.06 & 0.32 & 0.08 & 81.92 & $0.19,0.35$ & $0.21,0.41$ \\
\hline Mothers & 11 & 2416 & 0.33 & 0.19 & 0.14 & 0.13 & 0.40 & 0.15 & 53.96 & $0.25,0.41$ & $0.21,0.60$ \\
\hline \multicolumn{12}{|l|}{$\mathrm{Pa}$} \\
\hline Fathers & 11 & 2363 & 0.40 & 0.14 & 0.14 & 0.01 & 0.47 & 0.02 & 99.03 & $0.32,0.48$ & $0.45,0.49$ \\
\hline Mothers & 11 & 2416 & 0.40 & 0.11 & 0.14 & 0.01 & 0.47 & 0.01 & 100 & $0.32,0.48$ & 0.47 \\
\hline \multicolumn{12}{|l|}{$\mathrm{Pt}$} \\
\hline Fathers & 11 & 2363 & -0.17 & 0.23 & 0.14 & 0.18 & -0.18 & 0.20 & 36.51 & $-0.25,-0.09$ & $-0.43,0.07$ \\
\hline Mothers & 11 & 2416 & -0.20 & 0.26 & 0.14 & 0.22 & -0.22 & 0.24 & 27.99 & $-0.28,-0.12$ & $-0.52,0.09$ \\
\hline \multicolumn{12}{|l|}{$\mathrm{Sc}$} \\
\hline Fathers & 12 & 2423 & -0.23 & 0.22 & 0.14 & 0.17 & -0.26 & 0.19 & 40.07 & $-0.31,-0.15$ & $-0.50,-0.01$ \\
\hline Mothers & 12 & 2472 & -0.18 & 0.22 & 0.14 & 0.17 & -0.19 & 0.19 & 39.01 & $-0.26,-0.10$ & $-0.44,0.05$ \\
\hline \multicolumn{12}{|l|}{$\mathrm{Si}$} \\
\hline Fathers & 11 & 2363 & -0.38 & 0.18 & 0.14 & 0.11 & -0.43 & 0.12 & 60.06 & $-0.46,-0.30$ & $-0.59,-0.27$ \\
\hline Mothers & 11 & 2416 & -0.38 & 0.23 & 0.14 & 0.19 & -0.42 & 0.21 & 33.78 & $-0.46,-0.30$ & $-0.69,-0.15$ \\
\hline
\end{tabular}

\section{Discussion}

The results of this meta-analysis should be appraised in the light of certain limitations in the power of generalization that should not be overlooked. First, the results are not generalizable to those obtained in studies with feigning designs. Indeed, the results obtained in simulation studies in the context of forensic psychology differ significantly from those reported in field studies (Amado, Arce, Fariña, \& Vilariño, 2016; Fariña et al., 1994), which underscores the validity of the latter (face validity; Konecni \& Ebbesen, 1992). Second, the results were based on the comparison of parents and the normative population, and with scales for men and women, so comparisons with the control groups of the primary studies may offer slightly different results (control groups entail a normality bias), the same was applicable without scales for men and women (even with scales without gender, women reported more symptomology than men). Third, in the metaanalysis where the credibility interval had zero $(H s, D, P t$ and Sc scales), the results of the effect size, though significant, were not generalizable to all of the conditions since there were moderators in the relationship that could yield results of the opposite sign. Fourth, psychometric instruments are limited to providing diagnostic impressions that must be verified by a clinical interview. Bearing these safeguards in mind, the following conclusions may be drawn from the results. First, parents in child custody litigation systematically informed of differences in psychological adjustment as compared to normality (normative population). Notwithstanding, deviation was not relevant in all of the dimensions of report- ed normality. Thus, the effect sizes were less than small $(\delta<$ .20) in Hypochondriasis and Depression, with a probability of being classified as a clinical case (U2) of .013 and .012 in Hypochondriasis and Depression, rates below the general population (between .05 and .07 [Somatic Symptom Disorder]; and between .013 and .10 [Illness Anxiety Disorder] in Hypochondriasis, and around .07 in non-persistent depression) (APA, 2013). Second, self-reports close to normality in Depression and Hypochondriasis are indicators of denial of symptoms as couple break-down is strongly related to negative outcomes in Depression and Hypochondriasis (Afifi et al., 2006; Amato, 2010; APA, 2013; Blanco et al., 2017; Bourassa et al., 2017; Seijo et al., 2016; Zella, 2017). Succinctly, on these two dimensions, parents in child custody litigation concealed (feigned) clinical symptomatology depressive and somatic symptoms, and anxiety owing to illness (hypochondriasis passed to be renamed in DSM-5 as Somatic Symptom Disorder and Illness Anxiety Disorder). Third, the tendency of the reported deviation to normality was not systematic, that is, in some dimensions parents in custody litigation informed of higher levels of psychological maladjustment, but in others adjustment. Fourth, in Hysteria $(H y)$, Psychopathic Deviate $(P d)$, and Paranoia $(P a)$ clinical scales, parents in child custody litigation reported significant maladjustment that, in terms of clinical significance, was associated to increased classification rates of cases of Hysteria, Psychopathic Deviate, and Paranoia of 9, 7.1 and 9.5\%, respectively. High scores in these personality dimensions have been attributed to stress associated to separation and custody litigation, and high-conflict parental separations (Bathurst, Gott- 
fried, \& Gottfried, 1997; Ellis, 2012). From the perspective of the parents' cognition, high scores in hysteria informed of the denial of any problems, and the concealment of psychological problems (Graham, 2011). Moreover, high scores in Psychopathic Deviation were related to interpersonal conflicts similar to those encountered by ex-partners in court over child custody (the scale was positively and significantly correlated to the loss of family affection; Graham, BenPorath, \& McNulty, 1999), troublesome family relations, and problems within the couple (Pope, Butcher, \& Seelen, 2000). Since, Harris-Lingoes subscales comprise 'family' problems (9 items, measuring family disagreements), and 'social alienation (13 items, measuring the feelings that others do not understand them, things they regret they have done, feeling victimized). These cognitions (social alienation) and family problems are typical of parental disputes for child custody, which would explain the moderately high scores on this scale, but this is not to imply conscious subject response bias. These peaks return to the range of normality when conflict disappears (Greene, 2011). Likewise, elevated scores in paranoia may be explained as a reality (litigating parents do indeed feel persecuted, victims of a conspiracy, hated), not as a persecutory hallucination (persecutory hallucinations and persecutory perceptions are not equivalent, the former implies psychopathology and comorbidity, but not the latter; Senín-Calderón, Rodríguez-Testal, \& Perona-Garcelán, 2016), the main measurement objective of the scale. The Harris-Lingoes $\mathrm{Pa} 1$ subescale, 17 items, measures a persecution complex, when parents litigating for child custody feel persecuted or the victims of a conspiracy with evidence to prove it, the reports to the police (Ellis, 2000). Furthermore, the assumption of pathological traits, 'a persecution complex', implies they are unfounded, leading to a measurement error due to the method concluding this systematically (Arce, Fariña, \& Vilariño, 2015). Addtionally, the Harris-Lingoes $\mathrm{Pa} 2$ scale (Poignancy) expresses high nervousness, extreme sensitivity to criticism, and feel lonely and misunderstood, which are not specific to the context of separation and child custody litigation; and the $\mathrm{Pa} 3$ (Naivete) on parental denial of mistrust and hostility (denial of symptoms that are inherent to this evaluation setting, and clinical symptomatology associated to deficiencies in exercising child custody); and the adherence of parents to high moral standards, as well as being trustworthy, generous, altruistic, honest, with very optimistic attitudes about people (defensiveness should be suspected in the assessment in this setting). Hence, the $\mathrm{Pa} 3$ Scale has been positively correlated with the $K$ and $S$ defensiveness scales, whilst the $\mathrm{Pa} 1$ and $\mathrm{Pa} 2$ scales were negatively correlated (Nichols, 2011). Accordingly, a parent can obtain high scores, or even be classified as a clinical case without as- suming items of paranoid or bizarre ideation (Ellis, 2000). In short, the underreporting hypothesis (i.e., denial of clinical symptoms as these are linked to a lower probabilities of obtaining child custody) was selective, with self-reports on these dimensions being higher than in the normal population, which runs counter to the hypothesis of the general suspicion of feigning. Fifth, parents litigating for child custody scored significantly lower than the normative population in Psychasthenia $(P t)$, Schizophrenia $(S c)$, Hypomania $(M a)$, and Social Introversion $\left(S_{i}\right)$ clinical scales, with markedly less caseness classification rates (i.e., 6.2, 6.6, 3.4, and 10.4\% for $P t, S_{c}, M a$, and $S i$, respectively). Summarily, these parents not only deny symptomology in these dimensions, which is counterproductive to the goal of obtaining child custody, but also portray themselves in a positive light (Graham, 2011): confident and at ease with themselves, emotionally stable, persistent, capable, and motivated to success (low psychasthenia); conventional and realists (low schizophrenia); formal, reliable, mature, and thoughtful (low hypomania); and extroverted, and socially disposed (low social introversion). Hence, these dimensions combined both feigning strategies: denial of adverse clinical symptomatology, and ascribing to positive characteristics for exercising child custody. Sixth, litigating parents informed of similar psychological adjustment. Seventh, as for the assumed tacit correspondence between the restructured and clinical scales, the evidence is insufficient to conclude regarding the restructured scales.

In forensic practice two implications should be taken into account in the forensic evaluation. First, not all the parent population attempted to conceal clinical symptomology relevant for exercising child custody. Second, feigning should be suspected in forensic settings, and techniques should be applied for its precise detection and correct classification.

Future research should strive to search for moderators of deviations to normality (normative population) of selfreported psychological adjustment, given that the parent's gender had no impact, and the results inform of moderators mediating the effects of the relationship. This underscores the need for primary studies to identify potential variables moderating the effect, such as legal conflicts, or domains where injury associated to separation are to be found (Amato, 2010). Likewise, further studies are required to assess the self-reported adjustment of parents in child custody litigation on the restructured clinical scales.

Funding.- This research has been sponsored by a grant of the Spanish Ministry of Economy and Competitiveness (PSI201787278-R). 


\section{References}

\section{References marked with an asterisk indicate studies included in the meta-analysis}

Ackerman, J. J., \& Pritzl, T. B. (2011). Child custody evaluation practices: A 20-year follow-up. Family Court Review, 49, 618-628. https://doi.org/10.1111/j.1744-1617.2011.01397.x

Afifi, T. O., Cox, B. J., \& Enns, M. W. (2006). Mental health profiles among married, never-married, and separated/divorced mothers in a nationally representative sample. Social Psychiatry and Epidemiology, 41 122-129. http://dx.doi.org/10.1007/s00127-005-0005-3

Alonso, P., Moscoso, S., \& Salgado, J. F. (2017). Structured behavioral interview as a legal guarantee for ensuring equal employment opportunities for women: A meta-analysis. European Journal of Psychology Applied to Legal Context, 9(1), 15-23. https://doi.org/10.1016/j.ejpal.2016.03.002

Amado, B. G., Arce, R., Fariña, F., \& Vilariño, M. (2016). CBCA reality criteria in adults: A meta-analytic review. International Journal of Clinical and Health Psychology, 16(2), 201-210. http://dx.doi.org/10.1016/j.ijchp.2016.01.002

Amado, B. G., Arce, R., \& Herraiz, A. (2015). Psychological injury in victims of child sexual abuse: A meta-analytic review. Psychosocial Intervention, 24, 49-62. http://dx.doi.org/10.1016/j.psi.2015.03.002

Amato, P. R. (2010).Research on divorce: Continuing trends and newdevelopments. Journal of Marriage and Family, 72(3), 650-666. https://doi.org/10.1111/j.1741-3737.2010.00723.x

American Psychiatric Association. (2013). Diagnostic and statistical manual of mental disorders (5th ed.). Washington, DC: American Psychiatric Association.

American Psychological Association. (2010). Guidelines for child custody evaluations in family proceedings. American Psychologist, 49, 677-680. http://dx.doi.org/10.1037/a0021250

Arce, R., Arch, M., Fariña, F., Muñoz, J. M., \& Seijo, D. (2016). Estándares de evaluación psicológica forense en procesos de familia. In Sociedad Española de Psicología Jurídica y Forense y Asociación Española de Abogados de Familia (Eds.), Guía práctica sobre la prueba de especialistas en el marco del proceso de familia (pp. 31-41). Madrid, Spain: Sepin.

Arce, R., Fariña, F., \& Seijo, D. (2005). Razonamientos judiciales en procesos de separación: Análisis cognitivo y de contenido de las motivaciones [Judicial reasoning in parental separation and divorce proceedings: Content and cognitive analysis of judicial reasoning]. Psicothema, 17, 57-63. Retrieved from http://www.psicothema.com/pdf/3064.pdf

*Arce, R., Fariña, F., Seijo, D., \& Novo, M. (2015). Assessing impression management with the MMPI-2 in child custody litigation. $A s-$ sessment, 22(6),

769-777. http://dx.doi.org/10.1177/1073191114558111

Arce, R., Fariña, F., \& Vilariño, M. (2015). Daño psicológico en casos de víctimas de violencia de género: Un estudio comparativo de las evaluaciones forenses [Psychological injury in intimate partner violence cases: A contrastive analysis of forensic measures]. Revista Iberoamericana de Psicologia y Salud, 6(2), 72-80. http://dx.doi.org/10.1016/j.rips.2015.04.002

Archer, E. M., Hagan, L. D., Mason J., Handel, R., \& Archer, R. P. (2012). MMPI-2-RF characteristics of custody evaluation litigants. Assessment, 19(1), 14-20. http://dx.doi.org/10.1177/1073191110397469

Baer, R. A., \& Miller, J. (2002). Underreporting of psychopathology on the MMPI-2: A Meta-analytic review. Psychological Assessment, 24, 16-26. https://doi.org/10.1037/1040-3590.14.1.16

*Bagby, R. M., Nicholson, R. A., Buis, T., Radovanic, H., \& Fidler, B. J. (1999). Defensive responding on MMPI-2 in family custody and access evaluations. Psychological Assessment, 11, 24-28. https://doi.org/10.1037/1040-3590.11.1.24
*Bathurst, K., Gottfried, A. W., \& Gottfried, A. E. (1997). Normative data for the MMPI-2 in child custody litigation. Psychological Assessment, 9, 205-211. https://doi.org/10.1037/1040-3590.9.3.205

Ben-Porath, Y. S., \& Tellegen, A. (2008/2011). MMPI-2-RF (Minnesota Multiphasic Personality Inventory-2 Restructured Form): Manual for administration, scoring, and interpretation. Minneapolis. MN: University of Minnesota Press.

Blanco, V., Otero, P., López, L., Torres, Á., \& Vázquez, F. L. (2017). Predictores del cambio clínicamente significativo en una intervención de prevención de la depresión [Clinically significant predictors of change in an intervention for the prevention of depression]. Revista Iberoamericana de Psicología y Salud, 8(1), 9-40. https://doi.org/10.23923/j.rips.2017.08.002

Bourassa, K. J., Allen, J. J., Mehl, M. R., \& Sbarra, D. A. (2017). Impact of narrative expressive writing on heart rate, heart rate variability, and blood pressure after marital separation. Psychosomatic Medicine, 79 , 697-705. http://doi.org/10.1097/PSY.0000000000000475

*Butcher, J. N. (1997). Frequency of MMPI-2 scores in forensic evaluations. MMPI-2 News and Profiles, 8, 2-4. Retrieved from http:// citeseerx.ist.psu.edu/viewdoc/download?doi=10.1.1.501.85 $39 \& \mathrm{rep}=$ rep $1 \&$ type $=\mathrm{pdf}$

Butcher, J. N., Dahlstrom, W. G., Graham, J. R., Tellegen, A., \& Kaemmer, B. (1989). Manual for the restandardized Minnesota Multiphasic Personality Inventory: MMPI-2. Minneapolis, MN: University of Minnesota Press.

*Caldwell, A. B. (2004). [MMPI-2 cbild-custody dataset]. Unpublished

Cohen, J. (1988). Statistical power analysis for behavioral sciences (2nd ed.). Hillsdale, NJ: Erlbaum.

*Daskalakis, K. (2004). The use of the MMPI-2 in complex issues of bigh conflict child-custody disputes (Doctoral thesis, University of Toronto, Ontario, Canada). Retrieved from http://search.proquest.com/docview/305082915/6411BF7FAC0 B44F0PQ/5? accountid $=17253$

Ellis, E. (2000). Divorce wars: Interventions with families in conflict. Washington, DC: American Psychological Association.

Ellis, E. M. (2012). Are MMPI-2 Scale 4 elevations common among child custody litigants? Journal of Child Custody, 9(3), 179-194. https://doi.org/10.1080/15379418.2012.715547

*Ezzo, F., Pinsoneault, T. B., \& Evans, T. M. (2007). A comparison of MMPI-2 profiles between child maltreatment cases and two types of custody cases. Journal of Forensic Psychology Practice, 7(2), 29-43. https://doi.org/10.1080/15228932.2012.674469

Fariña, F., Arce, R., \& Novo, M. (2002). Heurístico de anclaje en las decisiones judiciales [Anchorage in judicial decision making]. Psicothema, 14, 39-46. Retrieved from http://www.psicothema.com/pdf/684.pdf

Fariña, F., Arce, R., \& Real, S. (1994). Ruedas de identificación: De la simulación y la realidad [Lineups: A comparison of high fidelity research and research in a real context]. Psicothema, 6(3), 395-402. Retrieved from http://www.psicothema.com/pdf/935.pdf

Fariña, F., Arce, R., \& Sotelo, A. (2010). ¿Es efectivo el estudio psicométrico estándar del peritaje del estado clínico y de la disimulación en progenitores en litigio por la guarda y custodia de menores? [Is effective the standard psychometric forensic evaluation of the mental health and faking good of the partners litigating by the child custody?]. Revista Iberoamericana de Psicologia y Salud, 1, 65-79. Retrieved from https: / / dialnet.unirioja.es/servlet/articulo?codigo $=3155226 \&$ orde $\mathrm{n}=408310$ \&info $=$ link 
Fariña, F., Redondo, L., Seijo, D., Novo, M., \& Arce, R. (2017). A meta-analytic review of the MMPI validity scales and indexes to detect defensiveness in custody evaluations. International Journal of Clinical and Health Psychology, 17(2), 128-138. https://doi.org/10.1016/j.ijchp.2017.02.002

First, M. B., Williams, J. B. W., Karg, R. S., \& Spitzer, R. L. (2015). Structured Clinical Interview for DSM-5 Disorders, Clinician Version (SCID-5-CV). Arlington, VA: American Psychiatric Association.

Glass, G. V. (1976). Primary, secondary, and meta-analysis research. Educational Researcher, 5, 3-8.

Glass, G. V., McGaw, B., \& Smith, M. L. (1981). Meta-analysis in social research. Beverly Hills, CA: Sage.

*Gordon, R. M., Stoffey, R., \& Bottinelli, J. (2008). MMPI-2 findings of primitive defenses in alienating parents. The American Journal of Family Therapy, 36, 221-228. https://doi.org/10.1080/01926180701643313

Graham, J. R. (2011). MMPI-2: Assessing personality and psychopathology (5th ed.). New York, NY: Oxford University Press.

Graham, J. R., Ben-Porath, Y. S., \& McNulty, J. L. (1999). MMPI-2 correlates for outpatient community health settings. Minneapolis, MN: University of Minnesota Press.

*Gready, P. A. (2006). Use of the MMPI-2 in child custody evaluations and child protection evaluations: An examination of defensive responding and psychopathology (Doctoral thesis, Universidad de Hartford). Retrieved from

https://search.proquest.com/docview/304958565/fulltextPDF/D 9A6A25E7F2C4C8EPQ/1? accountid=17253

Greene, R. L. (2011). The MMPI-2/MMPI-2-RF: An interpretive manual (3th ed.). Boston, MA: Allyn \& Bacon.

Hathaway, S. R., \& McKinley, J. C. (1940). A multiphasic personality schedule (Minnesota): I. Construction of the schedule. Journal of Psychology, 10 , https://doi.org/10.1080/00223980.1940.9917000

*Hopkins, L. (1999). The role of the $K$ scale as a validity measure in courtordered child custody MMPI's (Doctoral thesis, Kent State University, Ohio). Retrieved from https://search.proquest.com/docview/619446221/184D9C7FCF 38493DPQ/11? accountid=17253

Hunsley, J., Hanson, R. K., \& Parkeret, K. C. H. (1988). A summary of the reliability and stability of MMPI scales. Journal of Clinical Psychology, 44, 44-46.

Hunter, J. E., Schmidt, F. L., \& Jackson, G. B. (1982). Meta-analysis: Cumulating research findings across studies. Beverly Hills, CA: Sage.

*Kauffman, C. M., Stolberg, R., \& Madero, J. (2015). An examination of the MMPI-2-RF (Restructured Form) with the MMPI-2 and MCMI-III of child custody litigants. Journal of Child Custody, 12(2), 129-151. https://doi.org/10.1080/15379418.2015.1057354

Konecni, V. J., \& Ebbesen, E. B. (1992). Methodological issues on legal decision-making, with special reference to experimental simulations. In F. Lösel, D. Bender, \& T. Bliesener (Eds.), Psychology and law: International perspectives (pp. 413-423). Berlin, Germany: Walter de Gruyter.

*Mandappa, P. (2004). MMPI-2: The need for specific norms in child custody evaluations (Doctoral thesis, The Chicago School of Professional Psychology, Illinois). Retrieved from https://search.proquest.com/docview/305057409/184D9C7FCF 38493DPQ / 6 ? accountid $=17253$

Martindale, D. A., Martin, L., Autin, W. G., \& the Task Force Members (2007). Model standards of practice for child custody evaluations. Family Court Review, 45, 70-91. https://doi.org/10.1111/j.1744-1617.2007.129_3.x

Nichols, D. S. (2011). Essentials of MMPI-2 assessment (2nd ed.). Hoboken, NJ: John Wiley \& Sons.

*Normington, D. (2006). Caregiver competency evaluations: An examination of psychological characteristics of caregivers who neglect their children (Doctoral thesis, Pacific Graduate School of Psychology, California). Re- trieved

from

https://search.proquest.com/docview/304937462/C47F7B0B2E CA4917PQ/1 ?accountid $=17253$

*Ollendick, D. G., \& Collings, R. P. (1984). MMPI characteristics of parents referred of child custody cases. Journal of Psychology, 117 227-232. https://doi.org/10.1080/00223980.1984.9923682

*Pérez-Agüero, M. C., \& Verduzco Álvarez-Icaza, M. A. (2014). Evaluación psicológica con el MMPI-2 a padres en litigio judicial de materia familiar [Psychological assessment with the MMPI-2 of parents litigating in family courts]. Revista Intercontinental de Psicología y Educación, 16(2), 71-91. Retrieved from http://www.redalyc.org/pdf/802/80231541005.pdf

*Peters, K. M. (2012). Marital conflict in child custody disputes and the corresponding psychological variables (Doctoral thesis, Immaculata University, Pennsylvania). Retrieved from https://search.proquest.com/docview/1464395031/184D9C7FC F38493DPQ/24? accountid $=17253$

Pope, H., Butcher, J., \& Seelen, J. (2000). The MMPI and MMPI-2 in court: A practical guide for expert witnesses and attorneys (2nd ed.). Washington, DC: American Psychological Association.

Quinnell, F., \& Bow, J. (2001). Psychological tests used in child custody evaluations. Behavioral Sciences and the Law, 19, 491-501. http://dx.doi.org/10.1002/bsl.452

*Roma, P., Ricci, F., Kotzalidis, G. D., Abbate, L., Lubrano, A., Versace, G., Pazzelli, F., Malagoli, M., Girardi, P., \& Ferracuti, S. (2014). MMPI-2 in child custody litigation: A comparison between genders. European Journal of Psychological Assessment, 30, 110-116. http://dx.doi.org/10.1027/1015-5759/a000192

Rubio-Aparicio, M., Sánchez-Meca, J., Marín-Martínez, F., \& LópezLópez, J. A. (2018). Guidelines for reporting systematic reviews and meta-analyses. Annals of Psychology, 34, 412-420. https://doi.org/10.6018/analesps.34.2.320131

Sánchez, G., Ampudia, A., Jiménez, F., \& Amado, B. G. (2017). Contrasting the efficacy of the MMPI-2-RF overreporting scales in the detection of malingering. European Journal of Psychology Applied to Legal Context, 9(2), 51-56. https://doi.org/10.1016/j.ejpal.2017.03.002

*Schenk, P. W. (1996). MMPI-2 norms for child custody litigants. The Georgia Psychologist, 50(2), 51-54.

Schmidt, F. L., \& Hunter, J. E. (2015). Methods of meta-analysis: Correcting errors and bias in research findings (3th ed.). Thousand Oaks, CA: Sage.

Seijo, D., Fariña, F., Corras, T., Novo, M., \& Arce, R. (2016). Estimating the epidemiology and quantifying the damages of parental separation in children and adolescents. Frontiers in Psychology, 7, 1611. http://doi.org/10.3389/fpsyg.2016.01611

Senín-Calderón, C., Rodríguez-Testal, J. F., \& Perona-Garcelán, S. (2016). Las ideas de referencia y la preocupación por su presencia: Estudio sobre su relevancia para la caracterización de las psicosis [The ideas of reference and worry for their presence: Study on their relevance to the characterization of psychosis]. Revista Iberoamericana de Psicología y Salud, 7(1), 1-8. https://doi.org/10.1016/j.rips.2015.10.004

Simms, L. J., Casillas, A., Clark, L. A., Watson, D., \& Doebbeling, B. N. (2005). Psychometric evaluation of the restructured clinical scales of the MMPI-2. Psychological Assessment, 17(3), 345. http://dx.doi.org/10.1037/1040-3590.17.3.345

*Strong, D. R., Greene, R. L., Hoppe, C., Johnston, T., \& Olesen, T. (1999). Taxometric analysis of impression management and selfdeception on the MMPI-2 in child-custody litigants. Journal of Personality Assessment, 73, 1-18. http://dx.doi.org/10.1207/S15327752JPA730101

Tellegen, A., Ben-Porath, Y. S., McNulty, J. L., Arbisi, P. A., Graham, J. R., \& Kaemmer, B. (2003). MMPI-2 restructured clinical (RC) scales: Development, validation, and interpretation. Minneapolis: University of Minnesota Press. 
Vilariño, M., Arce, R., \& Fariña, F. (2013). Forensic-clinical interview: Reliability and validity for the evaluation of psychological injury. European Journal of Psychology Applied to Legal Context, 5(1), 1-21. Retrieved from http://scielo.isciii.es/pdf/ejpalc/v5n1/original1.pdf

*Wakefield, H., \& Underwager, R. (1990). Sexual abuse allegations in divorce and custody disputes. Behavioral Sciences \&o the Law, 9(4), 451-468. https://doi.org/10.1002/bsl.2370090408

Wicker, A. W. (1975). An application of the multitrait-multimethod logic to the reliability of observational records. Personality and Social Psychology Bulletin, $1, \quad 575-579$. https://dx.doi.org/10.1177/014616727500100405
*Wisneski, J. L. (2006). The MMPI-2 in contested child custody cases: Differences for parents in entrenched disputes (Doctoral thesis, Hofstra University, New $\quad$ York). $\quad$ Retrieved from https://search.proquest.com/docview/305324459/184D9C7FCF 38493DPQ/ 7 ? accountid $=17253$

Zella, S. (2017). Marital status transitions and self-reported health among Canadians: A life course perspective. Applied Research in Quality of Life, 12, 303-325. https://doi.org/10.1007/s11482-0169462-y 